\title{
The Evolution of International Fisheries Law and Policy Framework: A Paradigm Shift Towards Responsible Fisheries
}

\author{
Mohammad Zaki Ahmad
}

Abstract

The proliferation of international legal and policy instruments for fisheries governance during this post-LOSC era attests to the urgency and strong political commitment of the global community to improve and strengthen the international management and conservation framework for marine capture fisheries, fuelled in part by their mounting concerns over the pervasive unsustainable use and ineffective management of coastal and offshore fisheries worldwide. This paper aims to trace the historical origin and evolution of modern international fisheries regime, focusing on how the current legal and policy framework for - responsible fisheries came into being over the last two decades. A series of chronological events that led to this process is examined, stretching back to the periods from 1980s to 2001. Included in this paper is discussion on one of the important driving factors that led to the development global framework for the sustainable and responsible use and management of marine living resources: the need to address the inherent weaknesses of fisheries regime under the LOSC. Finally, the general background of international conferences, conventions, voluntary instruments that have played pivotal role in the development of responsible fisheries concept applicable to coastal States jurisdiction are presented in the paper by examining their scope of application and structure.

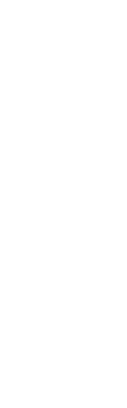

Keywords: Responsible Fisheries, UN Convention on Law of the Sea, IUU Fishing, Marine Fisheries, FAO Code of Conduct.

\section{Introduction}

International fisheries law and policy framework has undergone progressive changes in recent years and nowhere are these changes more evident than the emergence of responsible fisheries concept enshrined in various international and regional fisheries-related instruments. At the international level, the clearest reference to this concept inextricably links to a set of objectives, rules, principles, standards, and management measures found in a series of legally binding multilateral treaties, voluntary guidelines, declarations and resolutions. By far the most significant of these "hard law" and "soft law" instruments came into existence following the signing of the United Nations Convention on the Law of the Sea (LOSC) in 1982. ${ }^{1}$ All these instruments were called upon, negotiated, and adopted at different stages of meetings under the auspice of the UN General Assembly (UNGA) or the Food and Agriculture Organization (FAO). 
Among these post-LOSC instruments, the FAO Compliance Agreement, ${ }^{2}$ the UN Fish Stocks Agreement, ${ }^{3}$ and the FAO Code of Conduct for Responsible Fisheries ${ }^{4}$ have greatly influenced the conceptualization of responsible fisheries. ${ }^{5}$ Additional set of non-binding instruments, in which the core principle and measures for responsible fisheries were drawn, encompasses the four International Plans of Actions (IPOAs). Each individually deals with specific issues in fisheries, ranging from seabird by-catch, fishing capacity, and shark management, to illegal, unreported and unregulated (IUU) fishing. ${ }^{6}$

The concept of responsible fisheries dictates a more holistic and integrated approach for marine fisheries to be utilized and managed while striving to seek a balance between fulfilling socio-economic needs and maintaining the integrity of aquatic ecosystem and its diverse habitats. Some of the fundamental elements of responsible fisheries commonly found in the aforementioned post-LOSC fisheries instruments include, among others, accountability in the action and non-action of government and stakeholders engaged in fisheries management and fishing operation (Doulman, 2007); and application of science-

C based precautionary (González-Laxe, 2005; Cooney, 2004; Caddy \& Mahon 1995) and ecosystem-based approach (Sinclair et al., 2000; Lackey, 1999; Thomas, 1996) to decisionmaking and practical management in fisheries management. These principles and measures in some ways epitomize the general acceptance and inclination of international community to promote an alternative approach for fisheries management and conservation.

Such is the growing importance of responsible fisheries concept that it has been the subject of discussion in a considerable body of fisheries literatures. A particularly relevant illustration "of this trend is evident from the array of interpretations of the concept in recent years. Tsamenyi and Mfodwo (2002: p. 19), for example, refer "responsible fishing" as:

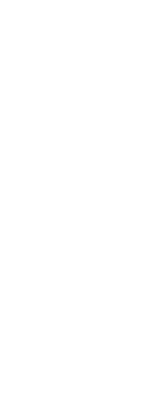
[A]n umbrella term used to describe a set of inter-related approaches to harvesting, conservation and management of fisheries resources with a strong emphasis on science-based management, the gathering and use of information to more closely control harvesting and conservation and management measures and a much more prescriptive approach to regulation of fishing activity.

Others authors engaged in different approach when interpreting "responsible fisheries." Sissenwine and Mace (2003: p. 363) shared similar view that responsible practice in fisheries, from the perspective of an ecosystem approach, means "sustainable production of human benefits, which are distributed "fairly," without causing unacceptable changes in marine ecosystems."

Despite the variation in interpreting responsible fisheries, the concept itself is of significance as it has now influenced, to a considerable extent, the behavior of national governments, regional fisheries management organizations (RFMOs) and stakeholders (e.g. non- 
government organization (NGO) and fishing industry) in the context of policy formulation and practical implementation of fisheries development, conservation and management. ${ }^{7}$

Notwithstanding the conceptualization process of responsible fisheries is of a recent origin, history shows that the concept was firmly grounded on the extensive efforts by international community since the mid-1980s to develop a more comprehensive and effective legal and policy measure with the aim to address the prevalent crisis in global marine fisheries. A host of legal deficiency and uncertainty in the international fisheries regime that remained during the years after the conclusion of the LOSC failed to reverse the declining state of fish stocks worldwide, within and beyond national jurisdiction (Fontaubert et al., 2003). The longterm sustainability of fisheries resources were (and continues to be) threatened, aggravated by various salient driving factors, ranging from overfishing and discard of unwanted bycatch species, deterioration of fragile marine ecosystem and its habitats from environmental pollution and destructive fishing practices, to reflagging of vessels. ${ }^{8}$ Such was the severity of these problems that it eventually triggered the catalysis for the existing global rules and management standards for marine capture fisheries to be re-assessed and subsequently revamped in numerous international fora and meetings organized under the purview of the FAO's Committee on Fisheries (COFI) and UNGA.

This paper, therefore, aims to trace the historical origin and evolution of modern international fisheries regime, focusing on how the current legal and policy framework for responsible fisheries came into being over the last two decades. A series of chronological events that led to this process is examined, stretching back to the periods from 1980 s to $2001 .{ }^{9}$ Included in this paper is discussion on one of the important driving factors behind the changing perception of international community to devise and develop a more stable and comprehensive global framework governing the sustainable and responsible use and management of marine living resources: the need to address the inherent weaknesses of fisheries regime under the LOSC. Finally, the general background of international conferences, conventions, voluntary instruments that have played pivotal role in the development of responsible fisheries concept applicable to coastal States jurisdiction are presented in the paper by examining their scope of application and structure..$^{10}$ The paper begins by examining the LOSC and its fisheries provisions, specifically under the exclusive economic zone (EEZ) regime.

\section{The LOSC and Its EEZ Fisheries Regime}

The LOSC arguably represents a profound achievement of the international community in developing a comprehensive and innovative international regime for ocean governance in the post-World War II era. ${ }^{11}$ The Convention is of significant importance in terms of setting up the legal foundation for many subsequently adopted international and regional instruments in dealing with the challenges and issues arising from the competing use of ocean space and marine resources, including fisheries, in the post-LOSC era. Such is the significance of the LOSC in the subsequent development of the global legal framework on the uses of oceans that Kaye (2001: p. 2) remarked the Convention represents "the dominant paradigm in contemporary marine living resource management." 
Drawing from its extensive 320 articles and 9 annexes, the LOSC has been rightly referred to by Ambassador Tommy Koh, the President of the Third United Nations Conference on the Law of the Sea (UNCLOS III), as the "constitution for the oceans," offering a comprehensive legal framework for governing virtually all facets of resources and activities associated with the oceans. ${ }^{12}$ Widely known as the first codified all-inclusive global legal instrument for ocean management, significant numbers of its provisions represent a statement of preexisting general rules, principles and norms regulating the use of ocean space and resources (Scheiber, 2001; Joyner, 2000). Nonetheless, not all the Convention's provisions are directly sourced from codified rules of existing customary international law (Amrasuriya, 2001). The LOSC does contain innovative principles, concepts and binding obligations which have transformed not only the traditional regime of the law of the sea, but international law in general (Pardo, 1983). Some of these novel provisions have gradually evolved into international customary law principles to which the International Court of Justice (ICJ) has periodically recognized in some of its landmark decisions. The EEZ regime is one such innovative features of the LOSC that has attained the status of customary international law and this is recognized under the ICJ judgment in Libya/Malta Continental Shelf case $(1985) \cdot{ }^{13}$

\section{Inherent Weaknesses of the LOSC Fisheries Legal Regime}

The international fisheries legal framework established under the LOSC was initially thought to provide a viable and effective solution for worldwide depletion and overexploitation of fish stocks in marine areas within and outside national jurisdiction. In reality, however, this framework has not been able to fully attain its objective due to the inherent weaknesses of $\int$ the Convention's fisheries provisions and the recurring failures of many States to exercise - their obligations for fisheries conservation and management effectively (Rayfuse, 1999). ${ }^{14}$

- Many commentators agree that the extension of coastal States' EEZ jurisdiction in the vast offshore fishing areas, even prior to the conclusion of the final session of UNCLOS III, did - not deliver the expected conservation benefits needed to address the pervasive problem of overfishing and environmental degradation (see Matt, 1976: p. 49; Tangsubkul and Fungwai, 1983: p. 9). Nor did the regime, in the opinion of Pardo (1983: p. 498), establishes effective legal mechanism and greater incentive for States to be more responsible in the way they utilised and managed fish stocks. Overall, Fontaubert et al., (2003); Miles and Burke (1989) share similar view that the fisheries regime established under the Convention has proven to be ineffective in compelling States to protect straddling and highly migratory fish stocks, and in resolving disagreements and disputes arising from fisheries conservation issues.

Towards the end of the 1980s to the early 1990s, evidences of State practices showed that numerous coastal and fishing States had failed to regulate excessive fishing efforts affecting transboundary fisheries, which in turn led to the problem of overfishing. ${ }^{15}$ Even countries traditionally known for pursuing best practices in fisheries management had not been spared from the devastating social and economic impact of the collapse of valuable pelagic and 
demersal fish stocks in their EEZs. Prominent example of such collapse occurred in the Atlantic groundfish fisheries in the Canadian EEZ off the east coast of Newfoundland, ${ }^{16}$ and the Northeast Arctic capelin fisheries of the Russian EEZ in the Barents Sea. ${ }^{17}$ The trend towards the serious decline, gross overexploitation and even total collapse of transboundary fish stocks in the EEZs worldwide inevitably raised doubt and scepticism over the ability, capacity and political will of States to discharge fully their stipulated obligations for conserving and managing these particular stocks.

The legal framework of the LOSC for marine fisheries management has its own shortcomings. Conspicuously missing from the Convention is an adequate legal framework prescribing clear and specific guidelines for States to conserve and protect straddling and highly migratory stocks. The LOSC falls short of offering precise guidance for relevant States in giving effect to their conservation and management obligations over the entire range of transboundary fish stocks between the EEZ and the high seas (Schram and Tahindro, 1999: pp. 253-254). From a legal standpoint, Rayfuse (1999) contends that the LOSC has placed too much emphasis on the jurisdictional issues of States without providing substantive guidelines for the conservation and management of transboundary fish stocks. Evidently, specific mechanisms or highly prescriptive procedures for giving effect to States' obligations on fisheries management, either directly or through regional organisation, are also missing from the text of the Convention (Juda, 1997: p. 149). As a result, the relevant States have faced difficulty in interpreting and applying the Convention's obligations to manage straddling and highly migratory fish stocks. ${ }^{18}$

- The second weakness of the LOSC with respect to the management of transboundary fisheries is that the obligation of relevant States to establish cooperative management for such fisheries is set in vague terms. Rayfuse (1999: pp.111-112) concludes that the weak nature of these particular provisions has given rise to "difficulty and disagreement over the interpretation and application of the provisions." Furthermore, the rather ambiguous language of the LOSC of requiring cooperation between States when dealing with the management of migratory fish species has been viewed by Oda (1989: p. xxii) as the primary factor undermining the effectiveness of fisheries conservation efforts on the high seas. Whilst the LOSC has placed firm obligations on high seas fishing States and adjoining coastal States to enter into negotiations in good faith and to reach agreement on the necessary measures for the conservation of affected straddling fish stocks on the high seas, there is no express obligation to reach agreement on this subject. ${ }^{19}$ Moreover, because the migration of these fish stocks typically spans multiple jurisdictional zones, transboundary cooperation for managing the stocks has become a critical component; otherwise, the conservation efforts of an individual State within its national jurisdictional waters might be rendered completely futile.

The LOSC, through Article 63(2), imposes a requirement on coastal States and high seas fishing States to seek cooperation with the objective of achieving a coherent management measure for transboundary fish stocks across their migratory range. Ironically, the rest 
of the Convention's articles do not provide specific mechanisms to assist those States in discharging this requirement. The precise manner in which to seek this cooperation has not been expressly elaborated. None of the provisions of the Convention, as stated by Hayashi (1995), explicitly mentions the consequences arising from the failure of States to reach a conservation agreement for straddling stocks. Articles 63(2), 64, 117 and 118 illustrate that the Convention's provisions are less than clear with regard to the exact nature and extent of the cooperation. Criticism by Davies and Redgewell (1996) and Tanaka (2008) has also been directed to Article 63(2) in which is silent on the specific temporary measures or procedures to be applied whilst the relevant States are waiting to reach an appropriate conservation agreement, or alternatively, the measures to be applied if the States concerned are unable to reach an agreement. Nothing in the Convention explicitly requires affected coastal States and States flagging their vessels to adopt a reasonable course of action designed to prevent overexploitation of the transboundary stocks. Adoption of provisions of this type would be helpful in overcoming problems associated with the on-going decline of straddling fish stocks, such as pollock. This is especially the case for those stocks found in the enclaves of

(1) the high seas bounded by EEZs of one or more coastal States, such as the 'Donut Hole' in the Central Bering Sea (e.g. Dunlap, 1995; Miouski, 1989), and 'Peanut Hole' of the Sea of Okhotsk (e.g. Elferink, 1995).

The reason why the negotiating parties had encountered difficulties in reaching an agreement with respect to the conservation measures for straddling fish stocks is that the provisions of the LOSC do not specify criteria for an acceptable allocation of harvesting rights over the stocks among the States fishing in those zones (Sullivan, 1997: p.110; Hoel, 2005: p. 44). It is widely recognised that in order for a fisheries conservation agreement to be successful, Pthe negotiating parties must allocate access to common fish stocks (Thébaud, 1997: p. 246.) - Apart from granting coastal States with the sovereign rights to exploit and manage marine - living resources within the EEZ, the Convention, according to Tanaka (2008: p. 62), is silent on the question regarding the distribution of fishing rights among all States - coastal - and high seas fishing States - over similar fish stock that straddle between the EEZ(s) and adjacent high seas. Practical application of the LOSC's obligations for the management of Iransboundary fish stocks is difficult when there is no specific mechanism or precise criteria to guide the relevant States in discharging their obligation in this area.

Another weakness of the LOSC's fisheries framework is its emphasis on a zonal approach to managing marine fisheries. This approach has also brought certain difficulties and one of which is the management of transboundary fish stocks with migratory patterns that cut across different jurisdictional zones. Not surprisingly, it failed to address effectively the continuing deterioration of commercially important transboundary fisheries populations (Juda, 1997: p. 148).

The underlying reason behind the ineffectiveness of this approach lies in its practical operation - one that is intrinsically linked to the universal partition of oceans and seas. Maritime frontiers are now divided into several zones of national jurisdiction (which extend 
out a distance offshore up to 200-nm from the territorial sea baseline) and the high seas. In turn, this delineation of maritime jurisdictional space has shaped the manner in which coastal and fishing States formulate and implement their fisheries policies and regulations within a specific zone in accordance to their varied assigned access rights and conservation duties over fisheries resources. Within national jurisdictional zone, coastal States possess the discretion to further subdivide maritime space into several segments of zones in order to promote the enhanced conservation of, and greater access to, fisheries resources. For instance, smaller fishing zones have been set up for traditional artisanal fisheries (normally in areas adjacent to the coastlines) and large-scale industrial fisheries (in areas farther offshore), as well as for other purposes such as maritime traffic safety, national marine parks, ports and military training. The approach to manage fisheries resources within the perimeter of States' jurisdictional zones undoubtedly disregards the temporal and biological distribution of various species of fish, as well as the ecological interaction between the fish stocks and their surrounding marine ecosystem (Kirk, 1999: p. 69). Churchill and Lowe (1999: p. 294) have further observed that the Convention's EEZ regime on fisheries seems to "convey the impression that most of the fish stocks only confine themselves to the EEZ of a single State." In reality, the boundary lines of EEZs in many parts of the world rarely coincide with the natural migratory boundaries of fish stocks (Hoel \& Kvalvik, 2006: p. 349). As previously stated, these stocks have a migratory range that spans across a number of EEZs and high seas areas. ${ }^{20}$ Hence, in view of the poor institutional fit between the migratory nature of the stocks and the designated maritime jurisdictional zones, the validity of the LOSC's zonal management approach as an effective regime for achieving the longterm conservation and sustainable utilisation of transboundary fish stocks is questionable.

-

Considering that the migratory range of transboundary fisheries generally cuts across several politically drawn maritime zones, it is highly unlikely that one State, acting independently, would be able to set up an effective and comprehensive management regime for these fisheries within its own national jurisdiction. Even if a State has adopted and enforced stringent conservation and regulatory measures for these fish stocks, there is always the possibility that these national initiatives would be undermined by unsustainable and irresponsible fishing practices in the vicinity of the high seas, or by ineffective fisheries conservation efforts in the EEZs of other States. The consequences from incompatible fisheries management measures in different maritime zones may pose the risk of mismanagement and/or inequality in the benefits to be gained from exploiting such stocks, leading to detrimental effect on the quality and quantity of straddling and highly migratory species within the EEZ of the said State.

In summary, the deficiency of the LOSC fisheries provisions, combined with the inability and refusal of a great number of coastal and fishing States to discharge their obligations and implement proper measures for fisheries conservation within national jurisdiction, has rendered fisheries conservation objectives under the Convention untenable. No matter how influential the EEZ fisheries regime under the LOSC towards providing socio-economic benefits to coastal States through access and exploitation of marine living resources, the regime has also been viewed by many to be flawed in ensuring sustainable development 
of such resources, particularly in respect to transboundary species such as straddling and highly migratory fish stocks. As a result, a multitude of fisheries-related issues emerged and persisted, predominantly in the form of overfishing, high rate of incidental catch and discard of non-target species, reflagging of vessels, and overcapitalisation. These problems have increasingly casted doubts on the comprehensiveness of the LOSC fisheries regime to reverse the trend of increasing depletion of fisheries resources and irresponsible fishing operations at global scale. This, in turn, prompted the need for a reform in the international legal and policy framework for fisheries.

By the late 1980s, a paradigm shift in the international fisheries regime was urgently needed. A new regime was required for closing the gaps that had been left by the LOSC fisheries framework, and equally significant, promoting a more sustainable, responsible form of fisheries practice in harmony with the environment. The succeeding sections will discuss this development in detail.

\section{(1) Reforming the Legal and Policy Contents of the Global Framework for Fisheries: A Paradigm Shift towards Responsible Fisheries}

In an effort to address the inherent weaknesses of the LOSC fisheries legal regime and the ongoing crisis in world fisheries, the global community increasingly called for the international legal and policy framework for fisheries governance to be re-assessed and revamped. There was an increased societal awareness for a paradigm shift towards a fisheries management regime that was more prescriptive, regulatory, and science-based in its approach and content. The push for the conceptualization of responsible fisheries regime started to gain momentum, and by early 1990s, was given a high profile in the international fisheries agenda at both regional and international levels. The following sections will - discuss the development of this regime, starting with the Nineteenth Session of the FAO COFI meeting in 1991.

"

\section{Nineteenth Session of the COFI Meeting}

The initial concept of responsible fishing and the call for a code of conduct establishing such a practice was formally raised at the Nineteenth Session of the FAO COFI Meeting that took place from 8-12 April, 1991 (hereafter 'COFI Meeting' or 'the Meeting'). ${ }^{21}$ Attended by government delegations and interested observers from different non-government organization, the agenda of the COFI Meeting was largely devoted to highlighting the issues and challenges facing the management of global fisheries, notably large-scale, pelagic driftnet fishing operations, as well as the scope for remedial action through individual and collective efforts. The Meeting also evaluated the progress, which had been made in implementing the Strategy and Programmes of Action endorsed by the 1984 FAO World Fisheries Conference for Fisheries Management and Development that was held in Rome, Italy, from 27 June to 6 July 1984. 
The COFI Meeting was far more influential in that it affirmed the decisive role the FAO would be expected to play in promoting responsible fisheries. The functional scope of the Organization would extend to, among others, enhancing the technical and scientific capabilities of governments and international/regional organizations in addressing the various issues in global fisheries and their habitats. In relation to this, the universality of FAO membership offers every State an opportunity to participate in the decision-making process of the Organization. Consequently, this arrangement has reinforced the status of the FAO as the most appropriate international body to deliver to States the technical guidelines and training programs for promoting sustainable development in fisheries and the protection of the aquatic environment.

The importance of the FAO to promote responsible fisheries practices has been further emphasized at the COFI Meeting, where the Organization decided to undertake different range of initiatives designed to achieve this objective. These initiatives included developing a standard vessel marking system and improved methods of vessel monitoring and enforcement, encouraging interstate cooperation, and enhancing national capabilities in the collection, analysis, reporting and dissemination of reliable fisheries statistics and data (FAO, 1991: pp. 14-15). Directing its attention to the broader issues of the use of nonselective fishing gear and urgent need for a reduction in the incidental capture of non-target fish species, the Meeting requested the FAO to intensify its work on the development of selective fishing gear technology and to assess the impact of such gear on marine animal behavior. In particular, the 1992 COFI Meeting raised the possibility of the FAO "elaborating guidelines or a code of practice for responsible fisheries which would take into account all the technical, socio-economic and environmental factors involved". ${ }^{22}$ This request was and persists to occupy the major thrust of the FAO's programme of work in the fields of fisheries and aquaculture, and received strong support from the international community, as illustrated in the convening of the International Conference on Responsible Fishing in Cancun, Mexico in 1992.

\section{Declaration of Cancun}

In response to the request made at the Nineteenth Session of the COFI Meeting for the FAO to draft a code of practice for responsible fisheries, the Mexican government, in collaboration with the FAO, hosted an International Conference on Responsible Fishing in Cancun, Mexico from 6-8 May 1992. Despite the fact that this was a low-key event with a narrow scope, it proved to be instrumental as a forum at which important groundwork could be carried out and triggered the development of a comprehensive code and set of standards and guidelines for responsible fishing (Tietze \& Izumi, 1999: p. 76).

After three day of deliberations and debates, the outcome of the Conference resulted in the adoption of the Declaration of Cancun, a non-binding document that intended to promote a completely different approach to fisheries management and development under the umbrella concept of "responsible fisheries". ${ }^{23}$ This new orientation marked a departure from the 
species-centric management approach (predominantly embedded under the LOSC fisheries regime) to a sustained, responsible utilization and management of fishery resources with a concurrent recognition on the protection of environment and related fisheries habitats. ${ }^{24}$ There are several numbers of key principles contained in the text of the Declaration of Cancun intended to ensure that fisheries and fishing activities are conducted responsibly:

\begin{abstract}
[S] ustainable utilization of fisheries resources in harmony with the environment; the use of capture and aquaculture practices which are not harmful to ecosystems, resources or their quality; the incorporation of added value to such products through transformation processes meeting the required sanitary standards; the conduct of commercial practices so as to provide consumers access to good quality products.
\end{abstract}

The above-mentioned principles could then be practically applied to fisheries management Cand conservation by urging States to take appropriate action for implementing a variety of measures proposed in the Declaration of Cancun. Examples of such measures central to this advocacy include: adopting effective fisheries planning and management standards (para. 10) and improving scientific knowledge relating to the biology, abundance, distribution and fluctuation of fisheries resources (para. 3). Other measures include promoting and enhancing the collection of data necessary for the conservation and sustainable utilisation of fisheries resources (para.4). Additional measures in the Declaration involve systematically assessing the impact of fishing, aquaculture and other activities on the marine environment (para. 7), fostering international cooperation and collaboration on matters relating to joint research, $C$ and facilitating the transfer and exchange of technological information on matters relating to fisheries (para. 16).

- 12

Specific measures addressing the factors and behaviours that attributed to irresponsible and - non-sustainable fisheries are also endorsed by the Declaration of Cancun. In particular, States are required to promote the development and use of selective fishing gear and selective fishing practices (para. 6), while flag States must abstain from reflagging vessels as a means of avoiding compliance with applicable conservation and management rules for fishing activities on the high seas. Indeed, Marashi (1996) asserts that these principles are a testimony to the urgent need at the time to reverse some of the most persistent and prevailing problems affecting global fisheries.

The 1992 Declaration of Cancun in general has placed the concept of responsible behavior in fisheries at the forefront of the international fisheries agenda. Equally important is the Declaration's recognition of the paramount role of the FAO to consult other international organizations for the preparation of an international code of conduct for sustainable and responsible fisheries. Beyond the organisational framework of the FAO, the call for the preparation of the code was so important that it became one of the main topics of debate at international fora immediately after the Cancun Conference. Most prominent of these 
fora was the United Nations Conference on Environmental Development (UNCED) (or popularly known as the "Earth Summit") that was held from 3-14 June 1992, in Rio de Janeiro, Brazil..$^{25}$

\section{UNCED and the Development of Responsible and Sustainable Fisheries Concept: The Rio Declaration and Agenda 21}

A list of long-standing issues relating to global resource sustainability and environmental

- protection received global coverage during the UNCED plenary sessions in 1992. The most critical issues were the overexploitation of aquatic living resources and the progressive deterioration of the vulnerable marine ecosystem, both of which needed remedial action by the international community. Concern over these issues eventually led to the creation of a series of progressive instruments, including framework document, action programme and declaration. ${ }^{26}$ Of these instruments, the Rio Declaration on Environment and Development (Rio Declaration) and the Programme of Action Agenda 21, specifically Chapter 17, typify the most significant achievement of the UNCED in the development of a global policy framework for promoting the sustainable use and responsible management of living resources within the context of marine environmental protection.

The contents of both the Rio Declaration and Agenda 21 share several similarities with respect to their underlying objectives and strategies in the aspects of promoting the concept of responsible fisheries. In particular, they each recognize the paramount importance of the governments of nation State as the main actors responsible to implement the documents' provisions and undertaking the appropriate action to ensure the sustainability and protection of the marine environment and its living resources. ${ }^{27}$ In this regard, the principles and measures in the two instruments offer guidelines on ocean law and policy reforms at the national and international levels, thereby making ecological and sustainable development of natural resources, including ocean and marine resources, attainable. ${ }^{28}$ Several principles expressed in the Rio Declaration and Agenda 21, including precautionary principles as well as those relating to international cooperation in fisheries management and ecosystem-based management approach in fisheries, replicate the important substance of responsible fisheries advanced in the Declaration of Cancun.

\section{Rio Declaration}

The Rio Declaration consists of 27 non-binding principles and nearly all of which focus on the sustainable and environmentally sound development of renewable natural resources, together with the protection of the environment and its biodiversity. At first sight, the Declaration is not a statement for marine fisheries governance per se. However, an examination on some of the concepts and principles embedded in the Declaration reveals their connection with the intrinsic elements of responsible practices in fisheries. The most obvious of these elements include an ecosystem approach to fisheries management, precautionary management principle and the emphasis on international cooperation in bringing about 
sustainable management and conservation in fisheries. To be more precise, Principle 4 of the Declaration deals with "Environmental Protection in the Development Process" and captures the essence of ecosystem approach to fisheries management and conservation. It starts by referring to a broad range of requirements for all States to implement as part of the sustainable development objective, one of which is environmental protection.

In recognition of the complex relationship between biological and physical components of ecosystems, components which often extend beyond the jurisdictional boundary of a single State, the Principle 7 of the Declaration places emphasis on the need for multilateral cooperation in order "to conserve, protect and restore the health and integrity of the earth's ecosystem". This collaborative approach is more efficient and cost-effective in addressing "environmental problems of a transboundary nature than the initiatives taken independently by individual States.

Another profound contribution of the Rio Declaration towards the development of a C contemporary international fisheries policy and legal framework for responsible fisheries is its adoption of a more cautious, science-based approach to the process of decision-making and management, now known as the precautionary principle. This principle is encapsulated in Principle 15 of the Declaration.

\section{Chapter 17 of Agenda 21}

Agenda 21 is perhaps one of the greatest achievements of the UNCED in that it has established a framework for guiding the global community in achieving both the sustainable development of critical resources, including fisheries, and the protection of the aquatic environment. A lengthy, non-binding document with worldwide implication, Agenda 21 - is an action blueprint for achieving good governance and sustainability in all areas of the world affected by human activities, including marine and coastal fisheries (Hanchard, 2004: p. 73). It is directed at both government and non-government organizations, and - places considerable emphasis on supporting States in designing and implementing their own national programme for the sustainable development of living resources. In addition, Agenda 21 serves as a mechanism for operationalising the different set of principles advanced in the Rio Declaration, including those principles, which, as noted earlier, constitute the conceptual framework for responsible fisheries.

Structurally,Agenda 21 is divided into 40 chapters with fourseparate sections ${ }^{29}$ encompassing both sectoral and interdisciplinary themes. ${ }^{30}$ Chapter 17 of Agenda 21 is probably the most important and complex chapter in terms of providing an appropriate course of action to secure the preservation and sustainable development of the environment and its resources (Naeve and Garcia (1995: 23). Although Chapter 17 of Agenda 21 is only a voluntary instrument, Basiron (1998) stresses that the instrument does affirm and complement the rights and obligations of States prescribed by maritime-related treaty instruments, most notably the LOSC, as well as those developed under the auspices of the IMO and other related bodies. 
The core elements of Chapter 17 are contained in seven programme areas, each of them supplemented by a series of objectives, activities and mechanisms for implementation. ${ }^{31}$ The overarching objective of these programme areas is to offer States and other non-government entities (whether international or regional) a set of guidelines to address specific matters relating to marine living resources and their ecosystem. It also has been a source of guidance and inspiration to those agencies responsible for the design and development of appropriate domestic programs for marine and coastal environment protection and the sustainable use of resources.

Consistent with the core principle of achieving responsible fisheries, Chapter 17 acknowledges that a more holistic approach is needed for the protection and conservation of marine and coastal ecosystems and their habitats. This is evident in paragraphs 17.74(e) and (f). States should take concrete steps to protect and restore endangered marine species, as well as preserve rare or fragile ecosystems, habitats and other ecologically sensitive areas. Accordingly, it has placed greater emphasis on an integrated management and sustainable development approach for coastal and marine areas and resources, rather than simply regulating fishing operations (Chapter 1 of Agenda 21, para. 17.1.) Not only must this development and management approach be integrated in its content; the same paragraph states that it must also be "precautionary and anticipatory in ambit". Indeed, all these principles represent the integral components of the international normative framework for responsible fisheries.

Another significant contribution of Chapter 17 in the global effort to solve prevalent problems in marine capture fisheries lies in its proposed management priorities, some of which are directed to overcome irresponsible, unsustainable and destructive fishing practices. Programme Area $\mathrm{C}$ of Chapter 17 in particular highlights international concern over the root cause and behaviour associated with the problem of fisheries management in the high seas and EEZs. Paragraph 17.45 of the Programme explicitly recognises the problem of overfishing affecting high seas fisheries, associating the cause of the problem to inadequate management, including the adoption, monitoring and enforcement of effective conservation measures. The same paragraph also identifies the management concerns prevalent in this fisheries sector, including unregulated fishing activities, overcapitalization, excessive fleet size, reflagging of vessels to avoid regulatory compliance and the use of non-selective fishing gear.

Another important contribution of Chapter 17 of Agenda 21 can be found in the recommendation made under paragraph 17.52(e) for the convening of an inter-governmental conference under the purview of the United Nations regarding the management and conservation of straddling fish stocks and highly migratory fish stocks. The outcome of this multilateral conference had eventually led to the adoption of the UN Fish Stocks Agreement. The following section discusses this particular legally binding instrument. 


\section{UN Fish Stocks Agreement}

The UN Fish Stocks Agreement was adopted on 4 August, 1995 at the sixth session of the UN Conference on Straddling Fish Stocks and Highly Migratory Fish Stocks. ${ }^{32}$ From a cursory examination of its preamble, 50 articles and 2 annexes, the drafters of the Agreement never envisioned for the instrument to operate as a comprehensive legal regime applicable to all types of fisheries. It is clear from its very title that the Agreement contains a narrow scope, being almost entirely devoted to securing the long-term conservation and sustainable utilisation of straddling and highly migratory fish stocks through effective implementation of the LOSC provisions. ${ }^{33}$

Despite the narrow scope of the UN Fish Stocks Agreement, the instrument has direct implications for the management regime of offshore fisheries within the EEZ. ${ }^{34}$ The Agreement offers "the incentive necessary for [coastal States to carry out] the most immediate changes in EEZ management" further enhance the duty of coastal States to 1 prevent problems of overfishing in the EEZ, as set forth in Article 61 of the LOSC (Christie, 2004, pp. 34-35). This assumption is premised on Articles 6 and 7 of the Agreement, which subsequently broaden the Agreement's fisheries management objective to include the conservation and management of straddling and highly migratory fish stocks specifically within areas of national jurisdiction.

The adoption of UN Fish Stocks Agreement marked a tremendous achievement of the international community towards improving the international framework of fisheries laws and regulations directed to transboundary fish stocks on the high seas and in the EEZs. As well as reiterating and supplementing international legal norms under the LOSC for the management of such stocks, ${ }^{35}$ Markoswki (2009) suggests that the treaty text of the Agreement placed greater focus on more prescriptive and cautious science-based measures and standards for the management of fisheries. ${ }^{36}$ According to Hayashi (1995), these measures and standards provide the basis for assisting States to implement effectively the LOSC provisions on the management of straddling and highly migratory stocks.

The very broad range of requirements prescribed under Article 5 of the Agreement is clearly designed to overcome the problems associated with irresponsible fishing practices affecting such stocks. These requirements - many of which qualify as the clearest expression of the concept of responsible fisheries directed to both flag and coastal States- relate to various matters. These matters include the development and utilization of selective and environmentally safe fishing gear (Article 5(f)); the generation and transmission of timely, complete and accurate data on various biological and operational aspects of fisheries (Article $5(\mathrm{j})$ ); and the prevention or elimination of overfishing and excessive fishing capacity (Article 5(f)). Others cover matters relating to the protection of biodiversity in marine environment (Article 5(g)); and effective monitoring, control and surveillance measures (Article 5(1).

Beside these general requirements, the UN Fish Stocks Agreement goes further by introducing innovative principles and new regulatory standards that are consistent with 
the central notion of responsible fisheries. Some of which include an ecosystem approach to fisheries, compatibility and consistency of fisheries management measures on the high seas and in EEZ and a precautionary approach to fisheries management and conservation (see Article 6 and Annex 11). The precautionary approach, one which encapsulates the core principles of the Agreement, is perhaps one of the most innovative principles in the international regime for fisheries management. Article 6 exemplifies this, being devoted entirely to the application of the precautionary approach. As such, it focuses more on the general obligation of the concerned State in implementing this approach, placing priority on science and information-based methodology to fulfil this obligation (Articles 6(3)(a) and $6(3)(d))$. In supporting the practical application of the Agreement's provisions on the precautionary approach to fisheries, Annex II of the Agreement contains specific technical guidelines on how States and RFMOs should implement those provisions.

The UN Fish Stocks Agreement also strengthens and expands the scope of duties of flag States already established under the LOSC and the FAO Compliance Agreement. Specific guidelines for States in exercising effective control and jurisdiction over vessels flying their State flag have been elaborated within the UN Fish Stocks Agreement. For example, Articles 18 and 19 reiterate the basic responsibilities of flag States contained in Articles III (1) and (3) of the FAO Compliance Agreement for the purpose of ensuring vessels fishing on the high seas comply with conservation and management measures. ${ }^{37}$ In short, the UN Fish Stocks Agreement offers much more depth and substance to the rights and responsibilities of flag States than the LOSC, and supplemented the FAO Compliance Agreement in preventing vessels from engaging in irresponsible and destructive high seas fishing practices.

\section{FAO Code of Conduct for Responsible Fisheries}

There are a number of soft law instruments emanating from the works of the COFI which seek to address the continuing crisis in global fisheries in the post-UNCED era. One prominent example is the FAO Code of Conduct for Responsible Fisheries (hereinafter the FAO Code of Conduct or the Code). ${ }^{38}$ Unanimously adopted on 31 October 1995 at the Twenty-eighth Session of the FAO Conference, the FAO Code Conduct is by far the most significant soft law instrument on fisheries ever developed, with its primary purpose being the promotion of the sustainable use of fisheries resources and responsible fishing practices, including in the aquaculture sector.

Considered "the most complete operational reference for fisheries management," 39 one of the most remarkable aspects of the Code is its complex and innovative set of principles, norms and standards for responsible fisheries practices which simultaneously acknowledge the importance of maintaining the integrity of the marine environment (e.g. Moore, 1999: p. 85; Hey, 1996: p. 483; Doulman, 2007: p. 191). Not only do these principles and measures serve as the basis for a universally accepted standard of responsible behaviour when harvesting fish, their intended application, as previously mentioned, clearly transcends the sectoral range of post-harvesting activities, from processing and trading, to the integration of fisheries into coastal area management. 
The FAO Code of Conduct is divided into 12 main Articles with two Annexes. ${ }^{40}$ The first five Articles of the Code are introductory in nature, ${ }^{41}$ with the substantive provisions of the Code are enumerated in Articles 6 to 12. The foundation of the Code can be found in Article 6 within which it contains 19 general principles under which the integral elements of the normative framework for responsible fisheries covered. Following these principles are six thematic articles, contained in Articles 7 to 12. Specifically, these Articles cover fisheries management (Article 7), fishing operations (Article 8), aquaculture development (Article 9), integration of fisheries into coastal area management (Article 10), post-harvesting and trade (Article 11) and fisheries research (Article 12).

In addition, the Code contains provisions concerning the need for States to prevent overexploitation of fisheries resources by: (i) ensuring the level of fishing intensity is commensurate with the state of those resources (Article 6.3); (ii) establishing interstate cooperative arrangements in fisheries for effective resource management and conservation (Article 6.4); and (iii) exercising effective control over vessels that fly their flags (Article 8.4). The Code also incorporates measures to foster the protection of the marine aquatic environment and the maintenance of biodiversity resources through the elimination of destructive, non-selective and environmentally unsound fishing gears and practices. ${ }^{42}$

One may argue that the elaboration of the FAO Code of Conduct represents the gradual progression and improvement of the modern international framework for fisheries governance. Rather than concentrating on a species-centric approach to fisheries management, Doulman (2007) elaborates that the main substance of this framework concentrates on managing human behaviour by fostering a culture of accountability and establishing an Cenvironmentally sound fisheries management process. The contribution of the Code, in - the view of Friedrich (2008: p.1548), extends beyond accommodating international rules - Of fisheries governance as it "constitutes a step forwards in the progressive development towards modern fisheries governance. Rather than being a static document, the framers of - the Code intended it to be a "living" one. As such, Article 4.3 of the Code indicates that its Substantive provisions were deliberately drafted to be capable of evolving in response to new emerging developments, scientific discoveries and practical experiences.

In spite that, the FAO Code of Conduct is not legally-binding (see Article 1.1), this does not mean it is devoid of a legally- binding effect in terms of overcoming global fisheries crisis in the EEZ areas and beyond. Fisheries stakeholders may not have legal obligation to implement the Code, or being subjected to punitive sanctions for non-compliance, but there is still a strong moral obligation on them to take the necessary action in implementing the Code (Hanchard, 2004: p. 75; Doulman, 2004: p. 46).

The Code's voluntary provisions are just as important as any other legally-binding treaty or obligatory instrument for two reasons. First, there is a clear link between the FAO Code of Conduct and other hard law instruments related to fisheries. Certain provisions of the Code are rooted in established principles of international law, and therefore may already 
have a legally binding effect, as would any hard law instrument. To this end, Article 3 explicitly requires the instrument to be interpreted and applied in a manner consistent with the LOSC. Article 3.2 of the Code further indicates the close relationship between this voluntary instrument and other existing legally-binding treaty instruments, namely the UN Fish Stocks Agreement. Second, the contents of the Code, though voluntary, could still be made compulsory wherever its provisions have been incorporated into domestic laws or regional agreements.

By virtue of the fact that the FAO Code of Conduct is a voluntary document and hence, without legally binding effect, States have no obligation to implement the Code's provisions unless a particular provision has either achieved the status of customary international law or has been incorporated into a State's national legislation. This arrangement does have its own advantages. States and fisheries stakeholders have virtually complete discretion when choosing which of the Code's principles and measures to implement, as well as the flexibility of tailoring these principles and measures to their individual capabilities and/ or changing circumstances. Since its adoption, the Code has served as a widely accepted reference point for the practical implementation of the responsible fisheries concept. While many countries, particularly developing coastal States, reportedly faced the difficulty in implementing the FAO Code of Conduct, ${ }^{43}$ there has been noticeable progress with respect to the legal and practical application of the Code among FAO members and Regional Fisheries Management Organizations (RFMOs) in relation to the management of marine capture fisheries. Based on a 2009 report by the COFI on the progress achieved in implementing the Code of Conduct and related IPOAs, it was reported that 93 percent of the respondents from 68 FAO member countries had put in place a national policy and legislative framework that either totally or partially conformed to the Code. ${ }^{44}$ Moreover, the function of the Code has been reinforced in recent years through the FAO's programme of work in fisheries that supports the dissemination and practical application of the principles and measures endorsed in the Code. An integral part of this programme is the introduction of a series of instruments linked to the Code - the four IPOAs. ${ }^{45}$ The following section briefly discusses these IPOAs.

\section{International Plans of Action (IPOAs)}

Within the first decade following the finalisation of the FAO Code of Conduct, COFI has developed a set of implementing instruments in the form of IPOAs. To date, these instruments consist of International Plan of Action for Reducing Incidental Catch of Seabirds in Longline Fisheries (IPOA-Seabirds), International Plan of Action for the Conservation and Management of Sharks (IPOA-Sharks), International Plan of Action for the Management of Fishing Capacity (IPOA-Capacity), and the International Plan of Action to Prevent, Deter, and Eliminate Illegal, Unreported and Unregulated Fishing (IPOA-IUU). The first three IPOAs- the IPOA-Seabirds, IPOA-Capacity and IPOA-Shark- were published in a single volume in $1999 .{ }^{46}$ This was followed by the endorsement of the IPOA-IUU document at the Twenty-fourth Session of the COFI on 2 March $2001 .^{47}$ 
As voluntary instruments elaborated within the framework of the FAO Code of Conduct, these IPOAs reinforce and supplement both the principles and objectives of the Code with regard to specific issues of affecting global fisheries, and hence form an integral part of it. Like the FAO Code of Conduct, these IPOAs are structured in accordance with international treaty instruments but incorporated a suite of principles, norms, standards and best practices designed to address specific global concerns in fisheries through responsible management practices. ${ }^{48}$

The IPOA-Sharks has been developed mainly to address the management and conservation of sharks due to their diminishing numbers resulting from lack of adequate management as waste and discards (see paras.4 and 7). The IPOA-Seabirds seeks to reduce the problems of incidental by-catch and mortality of seabirds in the longline fisheries industry through a host of proposed measures and activities. Concerns over unsustainable fishing levels in many parts of the world prompted the development of the IPOA-Capacity. It calls upon States to assess their fishing capacity, and if required, adjust or reduce their capacity in order to (C) overcome overcapitalisation and overfishing (Hosch, 2009).

-

As opposed to IPOA-Sharks and IPOA-Seabirds, which, according to Edeson, (2001: p. 608), "are very specific in their focus, the scope of the IPOA-Capacity extends beyond the general issue of fishing capacity, as evidenced by the inclusion of measures aimed to protect biodiversity and habitats in the marine environment from the adverse impact of fishing activities, such as the use of non-selective fishing gears (para. 9(iv)). From an operational standpoint of view, the IPOA-IUU contains substantive provisions that serve as useful guidelines for States and other interested actors in eliminating all forms of activities Passociated with IUU fishing within and outside their national jurisdiction.

When viewed as a package, the implementation of all four IPOAs is fundamentally important as they have the potential to reinforce, as well as deepen the implementation of the FAO - Code of Conduct. Non-obligatory principles and standards prescribed in the FAO Code of Conduct and the four IPOAs represent "wide areas of consensus within international community on many aspects of fisheries management" (Flewwelling et al. (2003: p. 17). The management measures contained in these IPOAs provide a comprehensive "toolbox", allowing States and relevant stakeholders the flexibility to choose which measures to implement according to their own capabilities and circumstances. All four documents seem to share the common goal of encouraging States to devise and adopt their own NPOA to ensure the effective management and sustainable exploitation of fisheries resources and fishing activities. In sum, the principles and measures of these four IPOAs, along with the FAO Code of Conduct, provide a valuable reference tool that may prove useful in guiding individual States in devising their own management and regulatory measures for responsible fisheries at national level. 


\section{Conclusion}

This paper has examined the historical origin and evolution of modern international fisheries regime over the last two decades, concentrating on the paradigm shift in the current legal and policy framework that inclines towards promoting responsible fisheries concept. The concept of responsible fishing was given form and substance through the introduction of a set of rules, general principles, standards, and management measures embodied in a series of legally binding and voluntary instruments subsequently adopted after the LOSC, most notably the UN Fish Stocks Agreement, the FAO Code of Conduct and the four IPOAs.

The proliferation of international legal and policy instruments for fisheries governance during this post-LOSC era attest to the urgency and strong political commitment of the global community to improve and strengthen the international management and conservation framework for marine capture fisheries, fuelled in part by their mounting concerns over the pervasive unsustainable use and ineffective management of coastal and offshore fisheries since the early $1980 \mathrm{~s}$.

While the post-LOSC instruments might differ in their scope, focus and legal status, they also share a number of attributes. In particular, they each contain a range of widely accepted principles and prescriptive requirements to address inadequacies as well as complement the rather loose and ill-defined fisheries framework of the LOSC. Equally important are underlying principles of these post-LOSC fisheries instruments to which represent a significant departure from the traditional species-centric management approach advocated

by the LOSC. Stronger priority is placed on accountability in harvesting and managing fish stocks, while taking into account the integrity of surrounding fisheries environment and its diverse habitats. The inclusion of several innovative principles that are central to the concept of responsible fisheries, such as ecosystem and precautionary-based fisheries management approach, is what differentiated these post-LOSC instruments from the traditional speciescentric approach to fishery conservation and management espoused in the LOSC.

-

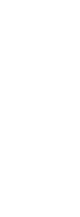

를

The profound changes in the global legal and policy framework for marine fisheries in the post-LOSC era offer some hopes that the dire state of global fisheries crisis can be addressed effectively. Nonetheless, no matter how comprehensive the current international framework for fisheries governance, its effectiveness to reverse this ongoing crisis ultimately depends on States' willingness, commitment and capacity to fully implement the framework. 


\section{End Notes}

1 The LOSC was opened for signature on $10^{\text {th }}$ December 1982 in Montego Bay, Jamaica, and came into force nearly 12 years later on November 16, 1994. The 1982 LOSC came into force a year after the $60^{\text {th }}$ country- Guyana- formally ratified the Convention.

2 FAO, Agreement to Promote Compliance with International Conservation and Management Measures by Fishing Vessels on the High Seas. Adopted under the auspice of the FAO on November 24, 1993, the Agreement came into force on 24 April 2003.

UN, Agreement for the Implementation of the United Nations Convention on the Law of the Sea of 10 December 1982 relating to the Conservation and Management of Straddling Fish Stocks and Highly Migratory Fish Stocks. The instrument entered into force on 11 December 2001.

FAO, Code of Conduct for Responsible Fisheries, hereafter referred to as FAO Code of Conduct or the Code. This voluntary instrument was adopted by consensus during the $28^{\text {th }}$ Session of the FAO Committee on Fisheries (COFI), in Resolution No. 4, on October $31^{\text {st }} 1995$.

Doulman, for example, has identified additional global instruments that made direct reference to the concept of sustainable utilization and responsible conduct in fisheries. These instruments include: the Declaration of the International Conference on Responsible Fishing Cancun, Mexico, 6-8 May 1992 (1992 Declaration of Cancun), Chapter 17 of Agenda 21, the 1992 Convention on Biological Diversity (CBD), the 2001 Reykjavik Declaration on Responsible Fisheries in the Marine Ecosystem (2001 Reykjavik Declaration), and the 2002 Plan of Implementation adopted by the Work Summit of Sustainable Development (WSSD-POI). See D. J. Doulman (2007), "Coping with the Extended Vulnerability of Marine Ecosystems: Implementing the 1995 FAO Code of Conduct for Responsible Fisheries," Social Science Information, 46, p. 191.

Specifically, these instruments are as follows: the International Plan of Action for Reducing Incidental Catch of Seabirds in Longline Fisheries (IPOA-Seabirds), the International Plan of Action for the Conservation and Management of Sharks (IPOA-Sharks), the International Plan of Action for the Management of Fishing Capacity (IPOA-Capacity) and the International Plan of Action to Prevent, Deter, and Eliminate Illegal, Unreported and Unregulated Fishing (IPOAIUU).

7 Much of the recent attention has been devoted on the extent of State practices in implementing the principles and management measures articulated in the FAO Code of Conduct for Responsible Fisheries. See the works by G. Hosch, G. Ferraro, and P. Failler (2011). "The 1995 FAO Code of Conduct for Responsible Fisheries: Adopting, Implementing or Scoring Results?," Marine Policy, 35, pp. 189-200. See also G. Hosch (2009). "Analysis of the Implementation and Impact of the FAO Code of Conduct for Responsible Fisheries since 1995," FAO Fisheries and Aquaculture Circular No. 1038, FAO, Rome, 99pp; and T. J. Pitcher, D. Kalikoski and G. Pramod (eds.) (2006). Evaluations of Compliance with the FAO (UN) Code of Conduct for Responsible 
The Evolution of International Fisheries Law and Policy Framework: A Paradigm Shift Towards Responsible Fisheries

Fisheries, Fisheries Centre Research Reports 2006 14(2), Fisheries Centre, University of British Columbia, Vancouver, B.C., Canada, 1191 pp.

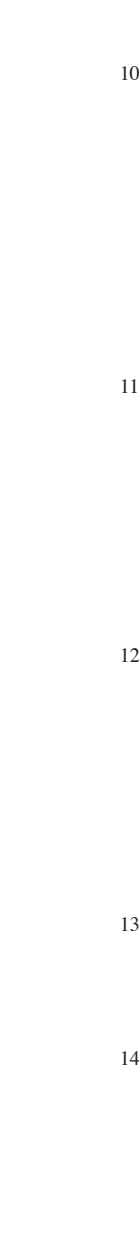

12 Singapore, President of the Third United Nations Conference on the Law of the Sea," in United Nations, The Law of the Sea: Official Text of the United Nations Convention on the Law of the Sea with Annexes and Index, U.N. Document A/CONF.62/122, U.N. Sales No. E.83.V.5, United Nations, New York, p. xxxiii.

Continental Shelf (Libyan Arab Jamahiriya/Malta), Judgment, ICJ Reports 1985, para. 34 at p. 33.

Rayfuse affirms that the jurisdictional framework embedded in the LOSC EEZ regime has proven to be an "inappropriate mechanism for the resolution of fisheries conservation and management issues." See R. Rayfuse. (1999). "The Interrelationship between the Global Instruments of International Fisheries Law," in Ellen Hey (ed.), Developments in International Fisheries Law, Kluwer Law International, The Hague, p. 111.

15

Meltzer provides a list of straddling fish stocks which have been subjected to overexploitation, including: pollock in the Bering Sea high seas 'Donut Hole'; orange roughy in the Challenger Plateau off New Zealand; hake, southern blue whiting and squid off Argentina's Patagonian Shelf; cod, American plaice, yellowtail and redfish off the Canadian Grand Banks in the Northwest Atlantic; jack mackerel off Chile and Peru; redfish in the Barents Sea 'Loop Hole' off Norway; and pollock in the Sea of Okhotsk 'Peanut Hole.' E. Meltzer. (1994). "Global Overview of Straddling and Highly Migratory Fish Stocks: The Non-Sustainable Nature of High Seas Fisheries," Ocean Development and International Law (ODIL), 25, p. 262. 
16 According to Steel et al., approximately 39,000 jobs were lost as a result of the collapse of the Newfoundland cod fisheries; while the Canadian government, as reported by Lyster, had to spend more than $\$ 730$ million alone in aid relief. See D. H. Steele, R. Andersen and J. M. Green (1992). "The Managed Commercial Annihilation of Northern Cod," Newfoundland Studies, 8 , p. 35; and M. L. Lyster. (1995). “Decimated Resources Fuel a Fish War,” San Diego UnionTribune, 19 April 1995.

See E. Orlova, A. Dolgov, S. Belikov and E. Johannesen. (2005). "Year-to-Year Dynamics of Trophic Links of the Main Commercial Fishes in the Barents Sea as Indicating the State of Ecosystem," in Vladimir Shibanov (ed.), Ecosystem Dynamics and Optimal Long-Term Harvest in the Barents Sea Fisheries, Proceedings of the 11th Russian-Norwegian Symposium, Murmansk, 15-17 August 2005, Institute of Marine Research (IMR) and Polar Research Institute of Marine Fisheries and Oceanography (PINRO), PINRO Press, Murmansk, Russia, pp. 1-7.

Apart from the difficulty in interpreting and applying the fisheries provisions of LOSC, Barston has identified additional factors, which may have contributed to the problems of management and conservation of transboundary fisheries, including vessel reflagging, insufficient scientific data on the accurate status of fish stocks and their supporting environment, including marine ecosystem, as well as enforcement problems in the EEZs and on the high seas. R. Barston (1995). "United Nations Conference on Straddling and Highly Migratory Fish Stocks," Marine Policy, 18, p. 160.

The duty to cooperate for the conservation of straddling fish stocks under Article 63(2) is only applicable in areas beyond the EEZ to the adjacent high seas. In contrast, Article 64 places a clear obligation on States to cooperate with respect to the conservation of these stocks across their migratory range. See Y. Tanaka. (2008). A Dual Approach to Ocean Governance: The Cases of Zonal and Integrated Management in International Law of the Sea, Ashgate International Law Series, Ashgate, Surrey, England, p. 64.

The migratory pattern of many principal commercial fish stocks, such as tuna and tuna-like species, are commonly characterized by their transboundary nature, crossing the artificial line of maritime boundaries. M. C. A. Ablan and L. R. Garces. (2005). "Exclusive Economic Zones and the Management of Fisheries in the South China Sea," in Syma A. Ebbin, Alf Håkon Hoel and Are K. Sydnes (eds.), A Sea Change: The Exclusive Economic Zone and Governance Institutions for Living Marine Resources, Springer, Dordrecht, p. 143.

21 The Session involved 87 members of the COFI, observers from 7 other FAO member nations, one non-Member Nation of the FAO (Taiwan), the Holy See, representatives from various UN organisations and European Economic Community, as well as observers from 14 IGOs and NGOs. See FAO (1991). "Report of the Nineteenth Session of the Committee on Fisheries, Rome, 9-12 April 1991," FAO Fisheries Report No. 459, FAO, Rome, p. 1.

Ibid., at p. 13. 
These programme areas encompass: (i) Integrated management and sustainable development of coastal and marine areas, including EEZs; (ii) Marine environmental protection; (iii) Sustainable use and conservation of marine living resources of the high seas; (iv) Sustainable use and conservation of marine living resources under national jurisdiction; (v) Addressing critical uncertainties for the management of the marine environment and climate change; (vi) Strengthening international, including regional, cooperation and coordination; and (vii) Sustainable development of small islands.

32 The Agreement was adopted on 4 December 1995 and came into force on 11 December 2001. As of March 2010, 77 countries have ratified or acceded to the Convention. The current status of the 
Agreement, including a list of contracting parties, as at 30 November 2010, is available online at http://www.un.org/Depts/los/reference_files/status2010.pdf (accessed on 11 August 2010).

33 Article 4 of the UN Fish Stocks Agreement expressly states that it must be interpreted and applied in the context of, and in a manner consistent with, the LOSC without "prejudice [to] the rights, jurisdiction and duties of States under the Convention."

M. Markowski. (2009). "The International Legal Standard for Sustainable EEZ Fisheries Management," in Gerd Winter (ed.), Towards Sustainable Fisheries Law: A Comparative Analysis, IUCN, Gland, Switzerland, p. 4.

B. Kwiatkowska, (Editor-in-Chief), H. Dotinga, E. Molenaar, A. O. Elferink, and A. Soons (CoEditors.) (2001). International Organizations and the Law of the Sea: Documentary Yearbook, Kluwer Law International, Dordrecht, p. 866; and M. Hayashi. (1995). “The 1995 Agreement on the Conservation and Management of Straddling and Highly Migratory Fish Stocks: Significance for the Law of the Sea Convention," Ocean \& Coastal Management, 29, p. 65.

Markowski states that that UN Fish Stocks Agreement places more importance on incorporating scientific evidence and information within the management and conservation framework for straddling and highly migratory fish stocks than the LOSC. The basis of her argument is that in contrast to Article 61(2) of LOSC, the requirement under the UN Fish Stocks Agreement (Article 5(b) for the conservation and management measures to be based on the best scientific evidence available is "a clearly normative requirement." Markowski, "The International Legal Standard for Sustainable EEZ Fisheries,” p. 14.

The UN Fish Stocks Agreement abandons the exemptions contained in the Compliance Agreement on fishing vessel less than 24 metres from the application of management measures.

The complete text of the Code is available online at http://www.fao.org/docrep/005/v9878e / v9878e00.HTM (accessed on 3 September 2010).

FAO Fisheries Department (2003). "The Ecosystem Approach to Fisheries," FAO Technical Guidelines for Responsible Fisheries No.4, Suppl.2, FAO, Rome, p. 80.

40 These two Annexes provide background information regarding the negotiation process that eventually led to the adoption of the Code; while the second one concentrates on the text of the FAO Conference Resolution of 4/95 pertaining to the Code's adoption.

41 These articles cover the nature, scope and objectives of the Code, its relationship with other international instruments, the implementation of the Code, as well as special requirements for developing countries. 
42 See, for example, Articles 6.6, 6.7, 5(f) and 6(3)(c), and 8.5 of the Code with respect to the development and use of selective fishing gear. See also Article 8.4.2 with respect to prohibition on the use of dynamite, poison and other destructive fishing practices.

43 These obstacles and constraints have been noted in the COFI's progress report on the implementation of the Code and include, among others, insufficient funding, a lack of technical and institutional capacity, inappropriate legislative frameworks for coastal fisheries, under-utilisation of the media and a lack of participation by stakeholders. The severity of this situation was further compounded by inadequate or lack of access to information in the field of fisheries research. COFI. (2001). "Progress in the Implementation of the Code of Conduct for Responsible Fisheries and Related International Plans of Action, Twenty-fourth Session, Rome, 26 February-2 March 2001, COFI/2001/3, 2001, paragraph 47, available online at http://www. fao.org/docrep/meeting /003/x9187e.htm (11 February 2011).

See COFI (2009). "Progress in the Implementation of the Code of Conduct for Responsible Fisheries, Related International Plans of Action and Strategy, Twenty-eighth Session, Rome, Italy, 2-6 March 2009," COFI/2009/2, 2009, paragraph 10, at p. 4, available online at ftp://ftp. fao.org/docrep/fao/meeting/015/k3833e.pdf (16 February 2011).

45 Adopted by the COFI at its Twenty-fifth Session Meeting in 2003, the instrument is intended to offer "a framework, strategy and plan for the improvement of knowledge and understanding of fishery status and trends as a basis for fisheries policy-making and management for the conservation and sustainable use of fishery resources within ecosystems." FAO (2003). Strategy for Improving Information on Status and Trends of Capture Fisheries, FAO, Rome, quoted from the abstract of the document.

All three documents were adopted by the COFI during the $23^{\text {rd }}$ session of its meeting in February 1999 and afterward endorsed by the FAO Council in June 1999.

47 The FAO Council formally endorsed the IPOA-IUU on 23 June 2001 during the $120^{\text {th }}$ session of the FAO Council in Rome, Italy.

B. Hanchard (2004). "The Implementation of the 1995 FAO Code of Conduct for Responsible Fisheries Management in the Western and Central Pacific," Appendix I, in FAO, FAO Fisheries Report No. 731, FAO, Rome, p. 76 


\section{References}

Ablan, M. C. A., \& Garces, L. R. (2005). Exclusive Economic Zones and the Management of Fisheries in the South China Sea. A sea change: The exclusive economic zone and governance institutions for living marine resources. Springer: Dordrecht, 136-149.

Amarasuriya, R. (2001). Third United Nations Conference on the Law of the Sea: An introductory insight. Sri Lanka Journal of International Law, 13, 137-158.

Barston, R. (1995). United Nations Conference on straddling and highly migratory fish stocks. Marine Policy, 18, 159-166.

-

Basiron, M. N. (1998). The implementation of chapter 17 of agenda 21 in Malaysia challenges and opportunities. Ocean \& Coastal Management, 41, 1-17.

Caddy, J. F., \& Mahon, R. (1995). Reference points for fishery management. FAO Fisheries Technical Paper No. 347, FAO, Rome: 82pp.

Christie, D. R. (2004). It Don't Come EEZ: The failure and future of coastal state fisheries management. Journal of Transnational Law \& Policy, 14, 1-36.

Churchill, R. R. \& Lowe, A. V. (1999). The law of the sea, (3rd Ed.). Manchester University Press: Manchester.

COFI. (2009). Progress in the implementation of the code of conduct for responsible fisheries, related international plans of action and strategy. Retrieved from ftp://ftp.

fao.org

COFI. (2001). Progress in the implementation of the code of conduct for responsible fisheries - and related international plans of action. Retrieved from http://www.fao.org

Cooney, R. (2004). The Precautionary Principle in Biodiversity Conservation and Natural Resource Management: An Issues Paper for Policy-Makers, Researchers and Practitioners, (pp.51) Gland, Switzerland and Cambridge: UK.

Davies, P., \& Redgewell, C. (1996). The international legal regulation of straddling fish stocks. British Yearbook of International Law, 67, 199-275.

Doulman, D. J. (2007). Coping with the extended vulnerability of marine ecosystems: Implementing the 1995 FAO code of conduct for responsible fisheries. Social Science Information, 46, 191-239.

Dunlap, W. V. (1995). The donut hole agreement. International Journal of Marine and Coastal Law, 10, 114-135. 
Edeson, W. R. (2001). The international plan of action on illegal unreported and unregulated fishing: The legal context of a non-legally binding instrument. International Journal of Marine and Coastal Law, 16, 603-623.

Elferink, A. G. O. (1995). Fisheries in the sea of okhotsk high seas enclave: The Russian federation's attempts at coastal state control. International Journal of Marine and Coastal Law, 10, 1-18.

FAO. Fisheries Department. (2003). The ecosystem approach to fisheries. FAO Technical Guidelines for Responsible Fisheries No. 4, Suppl. (p.2), FAO, Rome.

FAO. (2003). Strategy for improving information on status and trends of capture fisheries, (p.34) FAO, Rome.

FAO. (1999). Trends and issues relating to global fisheries governance addressed by the committee on fisheries (1977-1997). Retrieved from http://www.fao.org/docrep/ meeting/x0368e.htm

FAO. (1991). Report of the Nineteenth Session of the Committee on Fisheries. FAO Fisheries Report No. 459, (p.59), Rome.

Flewwelling, P., Cullinan, C., Balton, D., Sautter, R. P., \& Reynolds, J. E. (2003). Recent Trends in Monitoring, Control and Surveillance System for Capture Fisheries. (FAO Fisheries Technical Paper No. 415, p.200), Rome.

Fontaubert, C. D., \& Lutchman, I., with Downes, D., \& Deere, C. (2003). Achieving sustainable fisheries: Implementing the new international legal regime, (p.177). IUCN, Gland, Switzerland and Cambridge.

Friedrich, J. (2008). Legal challenges of nonbinding instruments: the case of the fao code of conduct for responsible fisheries. German Law Journal, 9, 1539-1564.

González-Laxe, F. (2005). The precautionary principle in fisheries management. Marine Policy, 29, 495-505.

Hanchard, B. (2004). The implementation of the 1995 FAO code of conduct for responsible fisheries management in the western and central pacific. FAO Fisheries Report 731, 72-87.

Hayashi, M. (1995). The 1995 agreement on the conservation and management of straddling and highly migratory fish stocks: Significance for the law of the sea convention. Ocean \& Coastal Management, 29, 51-69. 
Hey, E. (1996). Global fisheries regulations in the first half of the 1990s. International Journal of Marine and Coastal Law, 11, 459-490.

Hoel, A. H. \& Kvalvik, I. (2006). The Allocation of scarce natural resources: The case of fisheries. Marine Policy, 30, 347-356.

(2005). A Sea Change:The Exclusive Economic Zone and Governance Institutions for Living Marine Resources, Springer: Dordrecht. The performance of exclusive economic zones: The case of Norway. (p.33-48).

Hosch, G. (2009). Analysis of the Implementation and Impact of the FAO Code of Conduct - for Responsible Fisheries since 1995. (FAO Fisheries and Aquaculture Circular No. 1038, p.99) FAO, Rome.

Ferraro, G., \& Failler, P. (2011). The 1995 FAO Code of Conduct for Responsible Fisheries: Adopting, Implementing or Scoring Results? Marine Policy, 35, 189-200. See also G. Hosch (2009). Analysis of the Implementation and Impact of the FAO Code of Conduct for Responsible Fisheries since 1995. (FAO Fisheries and Aquaculture Circular No. 1038, p.99). FAO, Rome.

Joyner, C. C. (2000). The international ocean regime at the new millennium: A Survey of the contemporary legal order. Ocean \& Coastal Management, 43, 163-203.

Juda, L. (1997). The 1995 United Nations agreement on straddling fish stocks and highly - migratory fish stocks: A critique. Ocean Development \& International Law, 28, 147(N) 166.

ye, S. M. (2001). International Fisheries Management, Kluwer Law International, Dordrecht.

Kirk,E.A. (1999). Maritime zone and ecosystem approach: Mismatch? Review of European Community \& International Environmental Law (RECEIL), 8, 67-72.

Kwiatkowska, B. Dotinga, H; Molenaar, E; Elferink, A. O; \& Soons, A. (2001). International organizations and the law of the sea: Documentary yearbook. Kluwer Law International, Dordrecht.

Lackey, R. T. (1999). Radically contested assertions in ecosystem management. Journal Sustainable Forestry, 9, 21-43.

Lyster, M. L. (1995). Decimated resources fuel a fish war. San Diego Union-Tribune.

Marashi, S. H. (1996). Summary Information on the Role of International Fishery and Other Bodies with Regard to the Conservation and Management of Living Resources of the High Seas. (FAO Fisheries Circular No. 908, p.104). FAO, Rome. 
The Evolution of International Fisheries Law and Policy Framework: A Paradigm Shift Towards Responsible Fisheries

Markowski, M. (2009). The international legal standard for sustainable EEZ fisheries management. Towards Sustainable Fisheries Law: A Comparative Analysis, IUCN, Gland, Switzerland, 3-27.

Matt, J. C. (1976). Fishery and Resource Management in Southeast Asia, Resources for the Future, Washington, D. C. 62.

Meltzer, E. (1994). Global Overview of Straddling and Highly Migratory Fish Stocks: The Non-Sustainable Nature of High Seas Fisheries. Ocean Development \& International Law, 25, 255-344.

Miles, E. L., \& Burke, W.L. (1989). Pressures on the United Nations Convention on the Law of the Sea of 1982 Arising from New Fisheries Conflicts: The Problem of Straddling Stocks. Ocean Development \& International Law, 20, 343-357.

Miovski, L. (1989). Solutions in the Convention on the Law of the Sea to the Problem of Overfishing in the Central Bering Sea: Analysis of the Convention, Highlighting the Provisions Concerning Fisheries and Enclosed and Semi-Enclosed Seas. San Diego Law Review, 26, 525-574.

Moore, G. (1999). The Code of Conduct for Responsible Fisheries. Developments in International Fisheries Law, Kluwer Law International, The Hague, 85-105.

Naeve, H., \& Garcia, S. M. (1995). The United Nations System Responds to Agenda 21.17: Oceans. Ocean \& Coastal Management, 29, 23-33.

Oda, S. (1989). International Control of Sea Resources (Reprinted with New Introduction), Dordrecht: Martinus Nijhoff Publishers.

Orlova, E., Dolgov, A., Belikov, S., \& Johannesen, E. (2005). Year-to-Year Dynamics of Trophic Links of the Main Commercial Fishes in the Barents Sea as Indicating the State of Ecosystem. Ecosystem Dynamics and Optimal Long-Term Harvest in the Barents Sea Fisheries, Proceedings of the 11th Russian-Norwegian Symposium, Murmansk, 15-17 August 2005, Institute of Marine Research (IMR) and Polar Research Institute of Marine Fisheries and Oceanography (PINRO), (PINRO Press, Murmansk, Russia: 2005), pp. 1-7.

Pardo, A. (1983). The Convention on the Law of the Sea: A Preliminary Appraisal. San Diego Law Review, 20, 489-503.

Pitcher, T. J., Kalikoski, D. \& Pramod, G. (eds.) (2006). Evaluations of Compliance with the FAO (UN) Code of Conduct for Responsible Fisheries, Fisheries Centre Research Reports 2006 14(2), Fisheries Centre, University of British Columbia, Vancouver, B.C., Canada, 1191 pp. 
Rayfuse, R. (1999). The Interrelationship between the Global Instruments of International Fisheries Law. Developments in International Fisheries Law, Kluwer Law International, The Hague, pp. 107-158.

Scheiber, H. N. (2001). Ocean Governance and the Marine Fisheries Crisis: Two Decades of Innovation and Frustration. Virginia Environmental Law Journal, 20, 119-23.

Schram, G. G., \& Tahindro, A. (1999). Developments in Principles for the Adoption of Fisheries Conservation and Management. Developments in International Fisheries Law, Kluwer Law International, The Hague, 251-286.

Sinclair, M., Arnason, R., Csirke, J., Karnicki, Z., Sigurjonsson, J., Skjoldal, H. R., and Valdimarsson, G. (2002). Responsible Fisheries in the Marine Ecosystem. Fisheries Research, 58, 255-265.

(1) Sissenwine, M. P., \& Mace, P. M. (2003). Governance for Responsible Fisheries: An Ecosystem Approach. Responsible Fisheries in Marine Ecosystem, FAO and Cabi Publishing, Rome and Cambridge, 363-404.

Steele, D. H., Andersen, R., \& Green, J. M. (1992). The Managed Commercial Annihilation of Northern Cod. Newfoundland Studies, 8, 34-68.

Sullivan, M. S. (1997). The Case in International Law for Canada's Extension of Fisheries - Jurisdiction beyond 200 miles. Ocean Development \& International Law, 28, 203268.

- Tanaka, Y. (2008). A Dual Approach to Ocean Governance: The Cases of Zonal and Integrated Management in International Law of the Sea. Ashgate International Law Series, Ashgate, Surrey, England, p.288.

Tangsubkul, P., \& Fung-Wai, F. L. (1983). The New Law of the Sea and Development in Southeast Asia. Asian Survey, 23(7), 858-878.

Thébaud, O. (1997). Transboundary Marine Fisheries Management: Recent Developments and Elements of Analysis. Marine Policy, 21, 237-253.

Thomas, J. W. (1996). Forest service perspective on ecosystem management. Ecological Applications, 6, 703-705.

Tietze, U. \& Izumi, M. (Eds.) (1999). Selected Papers Presented at the Workshop on Economic Strengthening of Fisheries Industries in Small Island Developing States in the South Pacific, Apia, Samoa, 14-18, September 1998. (FAO Fisheries Report No. 596). FAO, Rome. 
Tsamenyi, M. B., \& Mfodwo, Kwame. (2002). Responsible Fishing and Access Agreements in the Western Central Pacific, A Report Commissioned by the Forum Fisheries Agency, Honiara, Solomon Islands, May 2002, p. 19, available online at Retrieved from http://www.spc.int/DigitalLibrary/Doc/FAME/FFA /ReportsFFA_2003_004. pdf

United Nations. (1983). A Constitution for the Oceans. Remarks by Tommy T. B. Koh, of Singapore, President of the Third United Nations Conference on the Law of the Sea. The Law of the Sea: Official Text of the United Nations Convention on the Law of the Sea with Annexes and Index, New York. 


$$
\begin{aligned}
& \text { हे } \\
& \text { כ } \\
& \overline{0} \\
& \text { (1) } \\
& \frac{\varepsilon}{\Xi} \\
& \text { ( ) } \\
& \sqrt{\square \quad} \\
& \text { 음 } \\
& \text { 政 } \\
& \text { ع }
\end{aligned}
$$

